Научная статья

УДК 2; 1

DOI: $10.18101 / 1994-0866-2021-1-57-63$

\title{
ТИПОЛОГИЯ НОВЫХ РЕЛИГИОЗНЫХ ДВИЖЕНИЙ: СОЦИОКУЛЬТУРНЫЕ ОСНОВАНИЯ КЛАССИФИКАЦИИ
}

\author{
(C) Ахмадулина Светлана Зиннатовна \\ кандидат исторических наук, \\ Бурятский государственный университет имени Доржи Банзарова \\ Россия, 670000, г. Улан-Удэ, ул. Смолина, 24а \\ lana_clio@mail.ru
}

\begin{abstract}
Аннотация. В данной статье проведен обзор новых религиозных движений, выявлены их общие и различные черты, проанализированы процессы их возникновения, закономерности их классификации в зависимости от критерия отношения к человеку, классификации по социокультурному признаку, а также по принципу происхождения. Сегодня религиозные новации подвергаются более пристальному вниманию со стороны исследователей, которые рассматривают это явление на стыке различных гуманитарных наук. Подобный интерес вызван не только увеличением количества организаций, численности верующих, что отражено в современных социологических исследованиях, но и новыми идеями, учениями или практиками сакрального и физического самосовершенствования, чуждыми религиозным традициям, доминирующим в порождающей их культурной среде. Классификация новых религиозных движений на основе критерия отношения к человеку и обществу позволяет оценить степень их влияния на приверженцев конкретных религиозных объединений.

Ключевые слова: новые религиозные движения; НРД; типология; неохристианство; неориентализм; неоязычество; New Age.
\end{abstract}

\section{Для цитирования}

Ахмадулина С. 3. Типология новых религиозных движений: социокультурные основания классификации // Вестник Бурятского государственного университета. Философия. 2021. Вып. 1. С. 57-63.

Новые религиозные движения (НРД) - это термин, который стал использоваться относительно недавно, преимущественно в работах зарубежных авторов, дальнейшая его популяризация приходится на 90-е гг. XX в. в России. В широком смысле новые религиозные течения - возникшие новые религии в XX в. и существующие в настоящее время [9, p. 6-7]. Есть различные термины, характеризующие новые религии - нетрадиционные религии, молодежные религии, альтернативные религии, тоталитарные секты, деструктивные культы и др. Использование определенной терминологии зависит от методологии изучения новых религий, конкретной авторской позиции. При всей разнородности состава нетрадиционных религий они все же представляют собой единую категорию типологическое явление иной религиозности, радикально отличающейся от традиционной для данного общества в рассматриваемый исторический период. Для них характерна интенсификация социальных функций религии, а часто и пропа- 
С. 3. Ахмадулина. Типология новых религиозных движений: социокультурные основания классификации

ганда новых социально-религиозных утопий обновленческой, оппозиционной либо альтернативной направленности, разработанных на основе радикально измененных (обычно нетрадиционных) вероучений [3, с. 3-11]

Среди научной литературы, анализирующей теоретические аспекты нетрадиционных религий, первостепенное значение имеют работы философов и религиоведов П. Антеса, А. Баркера, П. Кларка, Л. Н. Митрохина, Е. Г. Балагушкина, Н. А. Трофимчука, И. Я. Кантерова $[2 ; 4 ; 9 ; 10 ; 3 ; 13 ; 8]$ и др., в которых актуализируются основные проблемы возникновения и развития, раскрываются закономерности и особенности нетрадиционных религий. Особо следует выделить работы востоковедов С. В. Пахомова, А. А. Ткачева, Б. З. Фаликова, Ю. А. Иоаннесяна $[11$, с. 48-55; 12; 14; 7], изучавших историю, философию, религиозную психологию восточных религиозных новаций.

Членство в новых религиозных движениях, как правило, не является элитарным и доступно каждому независимо от его социального статуса, образования и иных критериев. При анализе возрастного состава общин обращает на себя внимание высокий процент молодежи - значительно выше, чем в организациях традиционных конфессий. Молодежь формирует особую субкультуру, которая придает религиозной группе характер «модного увлечения», служащего средством самовыражения и самореализации. Как правило, среди своих сверстников молодые люди не пользуются популярностью или успехом, для них община становится средством достижения собственных личных амбиций, механизмом достижения внутренней гармонии, поиска единомышленников и др. Обряды посвящения упрощены, от неофита не требуется обширной подготовки и знаний. Рекомендации определенного образа жизни не являются безусловными. Однако нарушения, дискредитирующие религиозную группу, влекут за собой исключение из ее рядов [15, p. 26].

Религиозное сознание в новых религиозных движениях характеризуется аморфностью, пластичностью религиозных положений, приоритет отдается религиозному опыту, а не закреплению религиозного опыта в строгих рамках канонов и догм. В религиозной практике преобладают магические символы: формулы (заклинания, мантры, молитвы), амулеты, тайные знаки, защищающие от влияния злых сил, дающие сверхъестественные силы для лечения болезней и т. д. Священнослужители, которые являются посредниками между человеком и сверхъестественным, либо отсутствуют, либо могут быть следующей ступенью посвящения, степенью знания.

В неоориенталистских движениях непосредственное руководство общиной, как правило, осуществляют не харизматические лидеры, а люди с хорошими организаторскими способностями, которые обычно не апеллируют к своим сверхъестественным качествам, приобретенным на пути самосовершенствования и самопознания. Это связано с мировоззрением восточных религий, которое постулирует индивидуальный путь к просветлению, начиная с преодоления эгоизма и несовершенства ума каждым человеком самостоятельно. Цель религиозной практики - не приобретение «заслуг» святого наставника, а личный путь восхождения к совершенству. Многие центры находятся под руководством приглашенных 
преподавателей, которые читают лекции широкой аудитории заинтересованных лиц, встречаются с кругом адептов, отвечают на вопросы, рассказывают о своем духовном опыте, дают советы и рекомендации по личным и организационным проблемам, практикуют совместные медитации и т. д. [6, p. 45].

В религиозных группах большое значение придается взаимопомощи и сплочению коллектива, что является одним из важных факторов привлечения верующих в свои ряды. С этой целью часто организуются совместные мероприятия, массовые фестивали, праздники, что способствует решению проблемы индивидуального отчуждения и актуально для больших городов. Взаимопомощь может выражаться как в реальной материальной форме, так и в психологической поддержке.

В России новые религиозные движения начали формироваться в 90-е гг. $\mathrm{XX}$ в., в период системного кризиса российского государства. Крушение идеологических основ советского государственного строя привело к массовому духовному поиску. В такой ситуации всплеск нетрадиционной религиозности общества стал неожиданным и неконтролируемым явлением для России, что привело к религиозному экстремизму, внедрению в систему образования, нарушениям прав человека в религиозных организациях. В настоящее время мы можем говорить о том, что высшая точка нетрадиционной религиозности пройдена, модернизирована законодательная база, регламентирующая деятельность религиозных организаций, а также деятельность религиозных новаций находится под наблюдением правоохранительных органов.

Современная религиозная ситуация в России определяется наряду с исторически сложившейся религиозной культурой, наличием атеистического мировоззрения среди определенной части общества, разнообразными по конфессиональной направленности новыми религиозными движениями, которые неодинаково представлены в различных регионах страны.

В европейской части России достаточно распространенными являются религиозные образования неязыческого типа, стремящиеся возродить архаичные, дохристианские духовные традиции, они удовлетворяют потребность в национальном самоопределении части российского общества. Другой тип новых религиозных движений представлен неохристианскими группами, которые видят квинтэссенцию русской духовности в христианстве, но конкретно осмысленном; часто они имеют фундаменталистскую направленность и открыто выступают против современной Русской православной церкви. Большинство новых религий в России обязаны своим происхождением деятельности миссионеров, главным образом из Европы и Америки, а также стран Азиатско-Тихоокеанского региона.

Сложность изучения НРД состоит в неоднородности и масштабности данного явления. В мире существует несколько тысяч различных религиозных новаций. Точное число последователей очень трудно установить, поскольку, с одной стороны, лидеры и приверженцы подобных движений целенаправленно преувеличивают число своих сторонников (либо занижают цифры), с другой стороны, в ряде новых религиозных движений верующие удовлетворяют свои религиозные 
С. 3. Ахмадулина. Типология новых религиозных движений: социокультурные основания классификации

потребности, оставаясь приверженцами какой-либо традиционной религии $[5$, p. 37].

НРД имеют широкий спектр представлений о сверхъестественном, отличаются составом верующих, отношением к миру, человеку, ареалом распространения и многими другими особенностями. Исходя из этого, нетрадиционные религии могут быть систематизированы на основе их идеологических источников, социокультурного контекста, отношения к личности и обществу.

Специфика представлений о сверхъестественном в нетрадиционных религиях во многом определяется влиянием основного идеологического источника. Содержательная база источника изначально трансформируется, сочетается с новыми религиозными идеями, ставятся иные акценты, меняются формы богослужения, объекты поклонения, и в результате формируется новая религиозная система ${ }^{1}$. По признаку происхождения новые религиозные движения можно классифицировать на следующие группы:

1. Нетрадиционные религии, которые трансформируют и переосмысливают религиозные доктрины мировых религий.

2. Неонациональные нетрадиционные религии, возникшие преимущественно на основе религиозно-философских положений национальных и государственных религий восточных стран, где процесс распространения мировых религий прошел незначительно или произошел синтез с национальными верованиями.

3. Неоязыческие нетрадиционные религии, возникшие в христианизированных или исламизированных регионах, имеющие форму возрождения архаических религиозных традиций.

4. Наукообразные нетрадиционные религии, возникшие на основе религиозной интерпретации научных теорий, гипотез, данных.

5. Оккультные нетрадиционные религии, использующие разнообразные представления о скрытых природных силах, которые могут быть использованы в практических целях.

Классификация религий по социокультурному контексту функционирования позволяет определить возможности конкретных религиозных объединений, которые сводятся к локальным, адаптивным, экуменическим типам.

1. Местные НРД распространены в определенном регионе и имеют сильную национальную и этническую принадлежность (неоязыческие группы, неошаманизм и др.). Религии этой группы подчеркивают свою культурную самобытность и практически не занимаются миссионерской и прозелитической деятельностью.

2. Адаптивные НРД выходят за пределы своего культурного ареала. Адаптация религии к совершенно иной социокультурной среде невозможна без ее качественного преобразования, популяризации, коррекции и даже полного устранения некоторых чуждых этой культуре теологических и этических принципов. К таким религиям относятся неоориенталистские религии (необуддизм, неоиндуизм), которые интерпретируют положения своей религии для последователей с

${ }^{1}$ Encyclopedia of new religions: new religious movements, sects and alternative spiritualities. Oxford: Lion, 2004. P. 21-22. 
иным менталитетом, но не включают в свое учение идеи, заимствованные из других религиозных учений.

3. В экуменических нетрадиционных религиях главной целью является объединение всех верований и всего человечества в единую религию («Вера бахаи», «Церковь объединения Сан Мен Муна» и др.). Последователи видят себя носителями последнего, истинного откровения и в различных странах мира ведут активную миссионерскую работу.

Классификация новых религиозных движений на основе критерия отношения к человеку и обществу позволяет оценить степень влияния на приверженцев конкретных религиозных объединений. В этом контексте выделяют нетрадиционные религии деструктивного и конструктивного типов [15, p. 65].

Деструктивные новые религиозные движения характеризуются следующими признаками: практика обманной вербовки адептов; требование разрыва всех социальных и семейных связей; контроль над сознанием и поведением человека; нанесение вреда психическому и физическому здоровью адептов; разделение на низшие и высшие уровни инициации; противостояние обществу и государству; критика традиционных религий.

Конструктивные новые религиозные движения обладают следующими признаками: открытость религиозной организации; свобода выхода из организации; программы, помогающие преодолеть наркотическую зависимость, алкоголизм, стресс, фрустрацию и др.; положительное влияние на психологическое здоровье человека; отсутствие изнуряющих религиозных обязательств; компромиссное отношение к обществу и государству; участие в религиозной жизни традиционных религий; проведение благотворительной деятельности.

Таким образом, представленные существующие типологии нетрадиционных религий, отраженные в работах зарубежных и отечественных специалистов в различных областях знаний, свидетельствуют о том, что выработка единой типологии - сложная научная задача. Каждый исследователь в соответствии с целями и задачами, описывая и анализируя религиозную жизнь того иного культурного ареала, выделяет и определяет как сущностные те или иные признаки. В целом же следует отметить, что при составлении типологии конфессиональные подходы предполагают отнесение к НРД всего спектра впервые привнесенных или возникающих религиозных феноменов. То есть все, объединяя под этим названием как вне вероисповедные формы мистики, оккультизма, так и крупнейшие, имеющие оригинальные вероучительные доктрины и практики объединения, нередко включая в список «новых культов» такие религии, которые в отечественном религиоведении определяются в качестве национальных и мировых [1]. Новые религиозные движения являются социальными и продолжают возникать и сегодня. Они очень разнообразны, но имеют ряд общих признаков, позволяющих классифицировать их. Генетически новые религиозные движения связаны с традиционными религиями, они возникли на их основе, но заимствование разнообразных элементов из традиционной религии, а зачастую и нескольких без глубокой религиозно-философской рефлексии характеризует религиозное сознание новых религий как эклектическую и синкретическую структуру. Востребо- 
С. 3. Ахмадулина. Типология новых религиозных движений: социокультурные основания классификации

ванность и популярность подобных движений обусловлена их ориентацией на исцеление, избавление от внутриличностных проблем, гармонизацию семейных и межличностных отношений и приобретение материальных благ в этом, земном, мире.

\section{Лuтература}

1. Ахмадулина С. 3. Правовое регулирование деятельности нетрадиционных религий в России (на материалах Республики Бурятия). Улан-Удэ, 2019. 280 с. $304 \mathrm{c}$.

2. Антес П. Религии современности. История и вера. М.: Прогресс-Традиция, 2001.

3. Балагушкин Е. Г. Нетрадиционные религии в современной России: морфологический анализ. М., 1999. Ч. 1. 244 с.

4. Баркер А. Новые религиозные движения. СПб.: РХИ, 1997. 282 с.

5. Davis Derek H., Barry Hankins. New Religious Movements and Religious Liberty in America. Waco: Baylor University Press, 2003. 238 p.

6. Benjamin E. Zeller Prophets and Protons: New Religious Movements and Science in Late Twentieth-Century America. N. Y., 2010. 240 p.

7. Иоаннесян Ю. А. Вера бахаи. СПб.: Азбука-классика, Петербургское востоковедение, 2009. $288 \mathrm{c}$.

8. Кантеров И. Я. Новые религиозные движения в России (религиоведческий анализ). M., 2006. $472 \mathrm{c}$.

9. Clark P. B. New Religions in Global Perspective: A Study of Religious Change in the Modern World. N. Y.: Routledge, 2006. 385 p.

10. Митрохин Л. Н. Религии «Нового века». М. : Сов. Россия, 1985. 157 с.

11. Пахомов С. В. Неотантризм в современной России // Аюрведа - наука жизни. 2007. № 1(15). C. 48-55.

12. Ткачев А. А. Новые религии Востока. М.: Наука, 1991. 216 с.

13. Трофимчук Н. А. Новые религиозные культы, движения и организации в России. М.: Изд-во РАГС, 1998. 346 с.

14. Фаликов Б. 3. Неоиндуизм и западная культура. М., 1994. 219 с.

15. Hammer Olav, Rothstein Mikael. New Religious Movements. N. Y.: Cambridge University Press, 2012. $341 \mathrm{p}$.

Статья поступила в редакцию 27.01.2021; одобрена после рецензирования 01.02.2021; принята к публикациии 09.02.2021.

\section{TYPOLOGY OF NEW RELIGIOUS MOVEMENTS: SOCIOCULTURAL GROUNDS FOR CLASSIFICATION}

Svetlana Z. Akhmadulina

Cand. Sci. (Hist.),

Dorzhi Banzarov Buryat State University

24a Smolina St., Ulan-Ude 670000, Russia

lana_clio@mail.ru

Abstract. The article presents an overview of new religious movements, identifies their common and different features, analyzes their classification by attitude towards a person, 
socio-cultural characteristics, and the principle of origin. Today, researchers pay much attention to religious innovations, they consider this phenomenon at the junction of various humanities. Such interest is caused not only by an increase in the number of organizations and believers, which is confirmed by modern sociological research, but also by new ideas, teachings and practices of sacred and physical self-actualization, alien to the religious traditions that dominate in the cultural environment. The classification of new religious movements by attitude towards a person and society allows us to assess their impact on the adherents of specific religious associations.

Keywords: new religious movements; typology; neo-Christianity; neo-Orientalism; neoPaganism; New Age.

For citation

Akhmadulina S. Z. Typology of New Religious Movements: Sociocultural Grounds for Classification. Bulletin of Buryat State University. Philisophy. 2021; 1: 57-63 (In Russ.).

The article was submitted 27.01.2021; approved after reviewing 01.02.2021; accepted for publication 09.02.2021. 